\title{
The Cumulative Effects of Sewage Sludge Compost on Raphanus sativus L: Growth and Soil Properties
}

\author{
Vanessa N. Lima', Ricardo V. Trótski O. Silva1, Patrícia Nunes', Paulo H. da Silva ${ }^{2}$, \\ Kyriale Morant ${ }^{2}$, Rosileide F. S. Andrade ${ }^{3}$, Aline E. Nascimento ${ }^{3}$, \\ Galba M. Campos-Takaki ${ }^{*}$, Arminda Saconi Messias ${ }^{3 *}$ \\ ${ }^{1}$ Development of Environmental Processes, Catholic University of Pernambuco, \\ Recife, PE, Brazil \\ ${ }^{2}$ Chemical Engineering Course, Catholic University of Pernambuco, Recife, PE, Brazil \\ ${ }^{3}$ Nucleus of Research in Environmental Sciences and Biotechnology, Catholic University of Pernambuco, \\ Recife, PE, Brazil \\ Email: "galba_takaki@yahoo.com.br, 'saconi@unicap.br
}

Received 15 October 2015; accepted 13 February 2016; published 16 February 2016

Copyright (C) 2016 by authors and Scientific Research Publishing Inc.

This work is licensed under the Creative Commons Attribution International License (CC BY).

http://creativecommons.org/licenses/by/4.0/

c) (i) Open Access

\section{Abstract}

The main goal of this research study was to establish the physicochemical characteristics of sewage sludge, and the nutrients needed to enhance the properties of soil with a view to exploiting were potential for agriculture. The example used was the cultivation of radish (Raphanus sativus). The findings are intended as a contribution towards making agriculture sustainable. This study was carried out to assess the response of radish (Raphanus sativus $L$.) to doses of sewage sludge applied in medium texture soils, and the socioeconomic contributions that such cultivation of radish would make. Levels of 0.25 and 75 ton/ha of sewage sludge plus the equivalent dose of 25 ton/ha of sewage sludge vermin compost by California Red were used after making a randomized experimental design with three replicates. 30 days after sowing radish seeds, the following data were collected: the number of leaves per plant (NLP); plant height $(\mathrm{PH}$ in $\mathrm{cm})$; root diameter (RD) and tubercle production (TP ton/ha). In addition, the pH, EC-electric conductivity (EC), and soil organic matter (SOM) were determined. Statistical analysis showed that 25 and 50 tons/ha gave the best results for the parameters assessed. The estimated increase in family mean income from selling radish crops fertilized with sewage sludge is around $17 \%$.

\section{Keywords}

Sewage Sludge, Productivity, Soil, Solid Waste, Raphanus sativus L.

\footnotetext{
${ }^{*}$ Corresponding author.
} 


\section{Introduction}

Problems arise when the wastes and pollutants generated by human activity are disposed of into the environment. Examples include those arising from domestic waste, sewage treatment, the production of crude matter, general services and from many other human activities. Therefore, research has taken an increasing interest in this problem since many of the chemical and biological properties of these kinds of waste can result in seriously jeopardy to public health and the environment [1]-[3]. Systems for treating residuary water are responsible for generating a significant amount of wastes, and their direct product is sewage sludge (SS). When it is possible to sterilize waste with calcium sulfate or carbonate, the product becomes a biosolid [4]-[6].

One of the alternative ways of disposing of Sewage sludge (SS), suggested in the literature, is to apply it in agriculture as soil fertilizer [7]-[16]. Nonetheless, a thorough study must be conducted regarding the use of SS in crop soil due to the different physical-chemical properties that these residues may contain and thus their applicability as fertilizer. Sewage sludge (SS) is known to be rich in nutrients (nitrogen and phosphorous), organic matter and trace elements that are beneficial for plant growth and better yield [15] [17]. Moreover, the study of using SS in agriculture ought to identify its role in reducing the costs of production as well as improving the environment and the impact on the quality of life of the communities involved [18].

According to Ramamurth et al. [19] and Camargo [20], radish is one of the oldest known root vegetables, with historical records of its cultivation dating back nearly 3 thousand years. Its most likely origin is in the south of Europe or southeast of Asia. In Egypt, crops date back to the Pharaonic Period while the ancient Greeks had a great appreciation for this vegetable: they served gold replicas as tributes to the Greek god Apollo. This vegetable was introduced in England and France in the 16th century, and around the 19th century, varieties of this plant were known in America and in Brazil. Radish has several attributes, such as it is a diuretic and anti-scorbutic; it stimulates the liver and digestive tract glandules besides which it has an anticancer role. Beyond these attributes, radish is an excellent source of calcium, phosphorus, iron, vanadium and of manganese. It contains B1 and B2 vitamins, nicotinic acid and vitamin C. Radish, if well washed and prepared, can be served raw, cooked, in salads or as pickles.

The quality of radish is assessed mostly by its external aspect, flavor and nutritional values. Hence, in order to increase the size and productivity of the radish crop and to improve the appearance of radish, farmers need to use heavy fertilization with mineral fertilizers so as to achieve a good market quotation for their crop. It is mineral fertilization which, in many cases, has the predominant impact on production in both technological and socioeconomic matters [21]. The amounts of fertilizer normally applied to the soil do not generally limit the growth or the productivity of the crops; however, if it is used in excess, fertilizer can adversely affect the plant's absorption of other nutrients [22] [23].

The production of high quality seedlings is one of the most important steps in the cultivation of root plants [24], because the final performance of the plants in the fields depends mostly on this stage [25] [26]. Radish is a widely cultivated species mainly in small farms located in greenbelts, and areas with highly diverse crops of root plants. It is an annual crop, of short cycle, producing a tuberous root with a round or long shape, which does not grow to depths of greater than between 45 and 60 centimeters deep. Its skin is red and its flesh white. The short cycle is an interesting aspect as radish can be grown as part of the rotation cycle in production systems where there are other crops which have long cycles, thus enabling the land to be used more rationally. Radish is an important species from the socioeconomic perspective but in general, this is seldom considered in research studies [27].

This study set out to establish the physicochemical characteristics of sewage sludge, and to investigate its nutrients with a view to using it to improve the soil and improve its potential for agricultural use so as to grow radish (Raphanus sativus) and increase the yield. This research also evaluates the effects on fertility of applying sewage sludge and assessing what socioeconomic contribution so doing may make to sustainable agriculture.

\section{Experimental Method}

\subsection{Location of Experimental Area}

The field study in support of this research project was conducted in an experimental area, sited in the United Families Community, in the neighborhood of Santa Mônica, in the town of Camaragibe, Pernambuco, Brazil, between September 2007 and March 2008. The $4500 \mathrm{~m}^{2}$ site is located in an irregularly occupied area, where 
local people engage on a multitude of socioeconomic activities (which includes cultivating root plants, fruits and vegetables, raising livestock, producing handicrafts and offering diverse services). The community which consists of four families who reside in four houses built in the territory is classified as a low-income community. The soil is classified as a latosolic, dystrophic Yellow Argisol (Brazilian Company of Agriculture and Livestock Research, EMBRAPA [28], in the semi evergreen Atlantic forest sub-region. The terrain is generally flat with few irregularities, originating from the sediments of the (tertiary) clay group. The soil, which is non-susceptible to erosion, has average texture, good to average internal drainage, low to average fertility and covers $10 \%$ of the State territory, belonging to the Northern Coast region of the state of Pernambuco.

In accordance with Köppen's classification which is used by the American Society of Meteorology (AMS), the dominant climate is rainy monsoon tropical with dry summers. The mean annual temperature is $24.8^{\circ} \mathrm{C}$ with a mean maximum temperature of $30.2^{\circ} \mathrm{C}$ and a mean minimum of $19.3^{\circ} \mathrm{C}$. The lowest temperatures are registered from June to September. The annual rainfall is $1,715.7 \mathrm{~mm}$, and the driest period occurs between October and December. The winds are light, with a mean speed of $159 \mathrm{~km}$ per day predominately in the South-Southeastern direction. The relative humidity is high, an average of $83 \%$, and evaporation is $2122 \mathrm{~m}$ a year as measured by a class evaporation pan [29]-[32].

\subsection{Physicochemical Characterization of the Soil}

Before radish is sown, a physicochemical characterization of the soil layer was made at depths from 0 to $20 \mathrm{~cm}$, in accordance with EMBRAPA [33]. This resulted in: $7.4 \mathrm{~g} \cdot \mathrm{kg}^{-1}$ of clay; $89.6 \mathrm{~g} \cdot \mathrm{kg}^{-1}$ of sand; $3.0 \mathrm{~g} \cdot \mathrm{kg}^{-1}$ of silt; $2.4 \mathrm{~g} \cdot \mathrm{dm}^{3}$ of organic matter, $20 \mathrm{mg} \cdot \mathrm{dm}^{-3}$ of Phosphorus (P), $0.15 \mathrm{mg} \cdot \mathrm{dm}^{-3}$ of Potassium (K); $3.4 \mathrm{mg} \cdot \mathrm{dm}^{-3}$ of Calcium (Ca); $0.55 \mathrm{mg} \cdot \mathrm{dm}^{-3}$ of Magnesium (Mg), $3.21 \mathrm{mg} \cdot \mathrm{dm}^{-3}$ of Sulphur (S); and Cation Exchange Capacity-CEC of $5.70 \mathrm{cmol} \cdot \mathrm{dm}^{-3}$. The total concentrations of potentially toxic elements were, in $\mathrm{mg} \cdot \mathrm{kg}^{-1}$ : Zinc (Zn) $=1.8$, Copper $(\mathrm{Cu})=1.5$, Manganese $(\mathrm{Mn})=5.0$, and Iron $=(\mathrm{Fe}) 1.6$.

\subsection{Chemical Characteristics of Sewage Sludge}

The sewage sludge used in the experiment was collected from the drying bed of the Sewage Treatment Station of the Integrated (Transport) Terminal of Pernambuco-ETE/TIP, in the city of Recife, state of Pernambuco, Brazil. This station treats domestic sewage. After the material was collected, it was prepared in order to assess its chemical composition according to APHA [34] (Table 1).

\subsection{Experimental Design}

The experimental design used was randomized blocks with five different treatments (zero, 25, 50 and 75 ton/ha of sewage sludge collected from ETE/TIP over 25 ton/ha of sewage sludge vermin compost by California Red) and three repetitions. The brickwork vegetable plots were one meter long by six meters wide and had a depth of $0.20 \mathrm{~m}$. They were divided into 21 rows with a space of $0.35 \mathrm{~m}$ between the rows and $0.15 \mathrm{~m}$ between the plants. The plants used in the assessments were the ones in the central area, the size of the useful area being two square meters.

\subsection{Treatments of Radish}

The (apagar: sowing of) radish (Raphanus sativus L.) was sown directly at a depth of $1.5 \mathrm{~cm}$, using 10 grams of seeds of the Crimson Giant cultivar per vegetable plot. After germination (from three to five days), the plants were thinned, thus leaving only those that presented well-developed foliage, as recommended by Ramamurthy et al. [19]. The usual treatments for the cultivation were carried out, including irrigation by aspersion up to twice

Table 1. Chemical characteristics of sewage sludge from the Sewage Treatment Station of the Integrated (Transport) Terminal of Pernambuco-ETE/TIP, in the city of Recife, state of Pernambuco, Brazil.

\begin{tabular}{|c|c|c|c|c|c|c|c|c|c|c|c|c|c|c|c|}
\hline $\begin{array}{c}\mathrm{pH} \\
\left(\mathrm{H}_{2} \mathrm{O}\right)\end{array}$ & $\begin{array}{c}\mathrm{P} \\
\mathrm{mg} \\
\mathrm{kg}^{-1}\end{array}$ & $\begin{array}{c}\mathrm{Cu} \\
\mathrm{mg} \\
\mathrm{kg}^{-1}\end{array}$ & $\begin{array}{c}\mathrm{Fe} \\
\mathrm{mg} \\
\mathrm{kg}^{-1}\end{array}$ & $\begin{array}{c}\mathrm{Zn} \\
\mathrm{mg} \\
\mathrm{kg}^{-1}\end{array}$ & $\begin{array}{c}\mathrm{Mn} \\
\mathrm{mg} \\
\mathrm{kg}^{-1}\end{array}$ & $\begin{array}{c}\mathrm{Cd} \\
\mathrm{mg} \\
\mathrm{kg}^{-1}\end{array}$ & $\begin{array}{c}\mathrm{Pb} \\
\mathrm{mg} \\
\mathrm{kg}^{-1}\end{array}$ & $\begin{array}{c}\mathrm{Na} \\
\mathrm{cmolc}^{-3} \mathrm{~d} \\
\mathrm{~m}^{-3}\end{array}$ & $\begin{array}{c}\mathrm{K} \\
\mathrm{cmolc}^{-3} \mathrm{~d} \\
\mathrm{~m}^{-3}\end{array}$ & $\begin{array}{c}\mathrm{Ca} \\
\mathrm{cmolc}^{\mathrm{d}} \mathrm{d} \\
\mathrm{m}^{-3}\end{array}$ & $\begin{array}{c}\mathrm{Mg} \\
\text { cmolcd } \\
\mathrm{m}^{-3}\end{array}$ & $\begin{array}{c}\mathrm{N} \\
\mathrm{g} \\
\mathrm{kg}^{-1}\end{array}$ & $\begin{array}{c}\mathrm{C} \\
\mathrm{g} \\
\mathrm{kg}^{-1}\end{array}$ & $\begin{array}{c}\mathrm{OM} \\
\mathrm{g} \\
\mathrm{kg}^{-1}\end{array}$ & $\mathrm{C} / \mathrm{N}$ \\
\hline 5.1 & 45 & 155 & 169 & 548 & 207 & 010 & 120 & 0.3 & 2.1 & 9.4 & 1.2 & 22.5 & 28.5 & 49.3 & 12.7 \\
\hline
\end{tabular}

(Values based on dry matter). 
daily, with a view to providing enough water for the good development of radish in the periods when precipitation was absent. Shading with banana leaves or palm-tree leaves was also used in order to avoid high levels of evapotranspiration in the warmest periods and the plot was manually weeded or with the aid of a hoe to keep the cultivation free from weeds. The radish was harvested 30 days after sowing, with sampling from the useful area previously assigned to each vegetable plot in 10 equidistant spots. An immediate count was made of the number of leaves per plant. The height of the plants was measured (in centimeters, from the base to the apex of the largest dimension of the leaf) as was the diameter of the roots (with a caliper rule and the data were collected in centimeters). The aerial part was promptly discarded after they were measured and the roots were washed and weighed. The average weight of each treated radish was calculated and the corresponding values converted to ton/ha in accordance with Yagioka et al. [35]. At the end of the harvest, the soil was sampled by collecting sub samples in a meandering pattern so as to form a compound sample per plot of which a chemical analysis ( $\mathrm{pH}$, EC, P, Organic Matter) was made as set out in the EMBRAPA [33] methodology. To evaluate how tendencies varied when concentrations were increased, a series of graphics was constructed using Statistic 6.0 [36] software. Thereafter, assays were made to assess which function would adjust best to each trend for which a series of mathematical and statistical parameters was obtained with a 95\% level of significance.

\section{Results and Discussion}

\subsection{Leaves, Plant Height, Root Diameter and Tubercle Production}

The results showed the number of leaves per plant (NLP), plant height $(\mathrm{PH}$ in $\mathrm{cm})$, root diameter (RD in $\mathrm{cm}$ ), and tubercle production (TP ton/ha) all increased as described in Table 2. Figure 1 shows diagrams of the dispersion tendency of dependent variables when the treatment values are varied. In the analysis of the characteristics of the plant regarding the number of leaves produced (Table 2, Figure 1(a)) note that when a level equivalent to 25 ton/ha of sewage sludge was used both "in natura" and vermin composting, the number of leaves in the radish cultivated increased. The statistical response showed no difference until a dose 50 ton/ha of sewage sludge was reached. These numbers are superior to those found, which surpass numerically the corresponding level of 75 ton/ha, although no statistical difference between them was found. The same pattern was observed regarding plant height (Table 2, Figure 1(b)). Initially, the radish grew slowly, though, at the end of the cycle, the estimated production was 18.02 ton/ha when levels of 25 ton/ha of sewage sludge were used (Table 2, Figure 1(c)). A large investment in the aerial part was perceived. This was naturally expected so as to establish the organs that would be the source of photoassimilate. Similar results were observed by Nunes et al. [37] and Haag and Minami [38] in beetroot and by Muller et al. [22] in radish. It was also observed that when levels corresponding to 25 and 50 ton/ha of sewage sludge and 25 ton/ha of sewage sludge vermin compost were used, the production of radish continued to be produced in the acceptable interval for this vegetable (15 to 20 ton/ha), according to Yagioka et al. [35]. Therefore, the potential for using sewage sludge in agriculture becomes evident. The estimated increase in mean family income with radish fertilized with sewage sludge was approximately $17 \%$. The results showed higher values for TP (ton/ha), an increase to $43.47 \%$ using $25 \mathrm{SS}$, and the cost of production according the Table 2 the income per plot was US $\$ 6.20$ on comparing controlled treatments.

Table 2. Median values related to number of leaves per plant (NLP), plant height $(\mathrm{PH} / \mathrm{cm})$, root diameter (RD/cm) and tubercle production (TP ton/ha) obtained 30 days after sowing the "Crimson Giant” cultivar of radish, and the income per plot from each different treatment.

\begin{tabular}{cccccc}
\hline Treatments $^{1}$ (ton/ha) & NLP & PH $(\mathrm{cm})$ & RD $(\mathrm{cm})$ & TP (ton/ha) & INCOME PER PLOT $^{3}$ (US\$) \\
\hline $0 \mathrm{SS}$ & $5.0 \mathrm{~b}^{2}$ & $10.4 \mathrm{~b}$ & $3.56 \mathrm{~b}$ & $12.56 \mathrm{c}$ & 4.32 \\
$25 \mathrm{SSV}$ & $7.7 \mathrm{a}$ & $17.2 \mathrm{a}$ & $4.12 \mathrm{a}$ & $17.45 \mathrm{~b}$ & 6.01 \\
$25 \mathrm{SS}$ & $7.6 \mathrm{a}$ & $17.8 \mathrm{a}$ & $3.95 \mathrm{a}$ & $18.02 \mathrm{a}$ & 6.20 \\
$50 \mathrm{SS}$ & $7.5 \mathrm{a}$ & $17.5 \mathrm{a}$ & $3.87 \mathrm{a}$ & $17.66 \mathrm{~b}$ & 6.08 \\
$75 \mathrm{SS}$ & $4.2 \mathrm{~b}$ & $12.7 \mathrm{~b}$ & $3.42 \mathrm{~b}$ & $12.06 \mathrm{c}$ & 4.14 \\
Total & - & - & - & - & 26.79 \\
\hline
\end{tabular}

${ }^{1} \mathrm{SS}$ = sewage sludge; VSS = vermin compost sewage sludge by California red. ${ }^{2}$ Average values followed by the same letter had no difference between them by the Tukey test at $5 \%$ probability. ${ }^{3}$ sold as radish sauce $=129$ grams. 


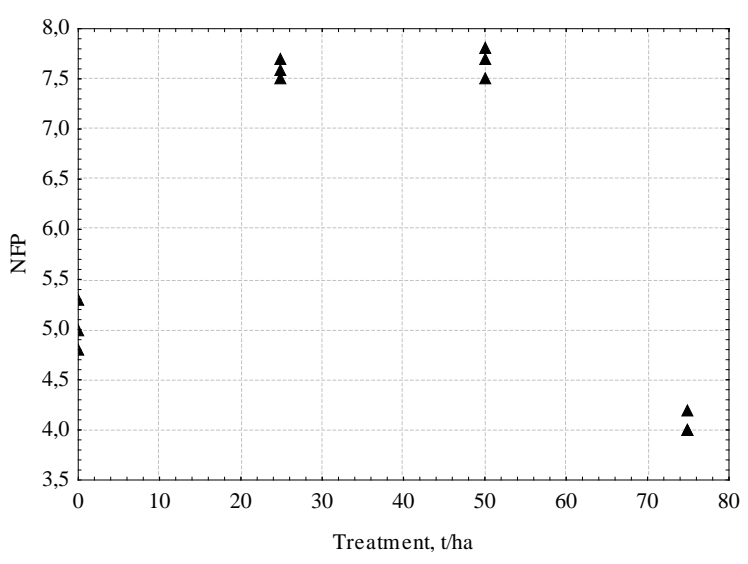

(a)

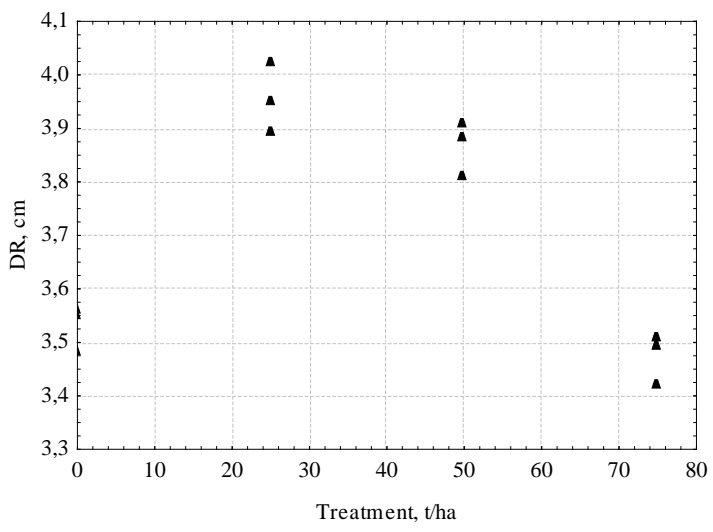

(c)

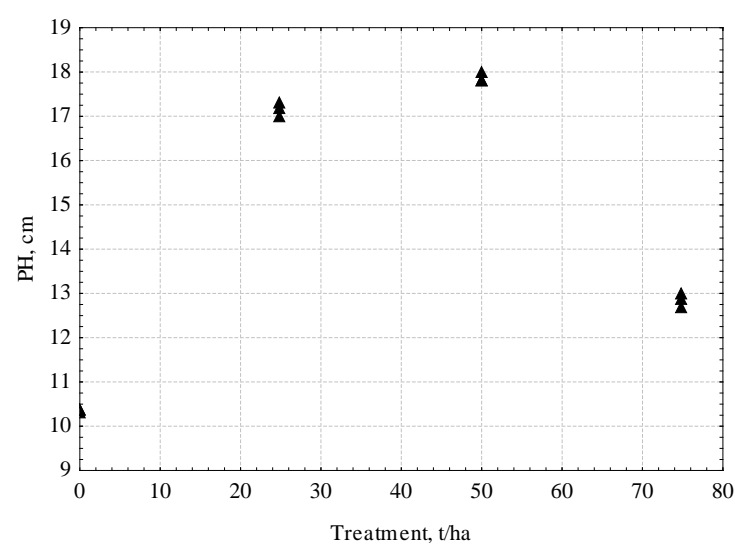

(b)

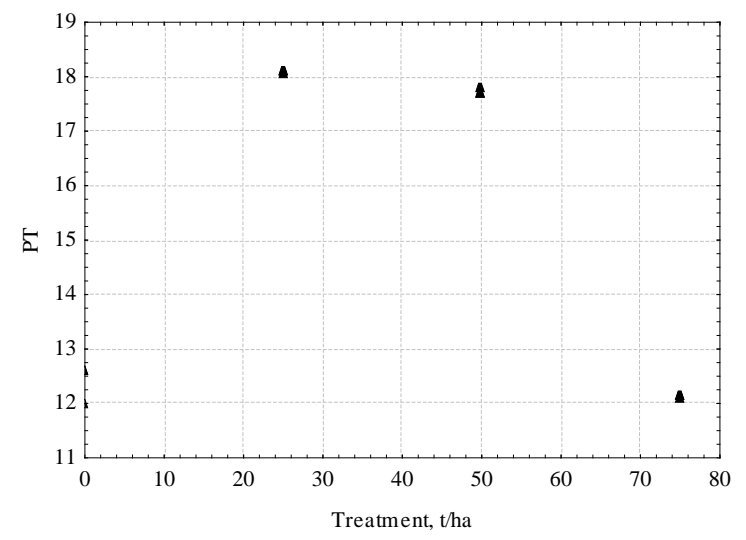

(d)

Figure 1. Behavior of (apagar: de) the dependent variables related to treatments of $0,25,50$ and 75 ton/ha of sewage sludge + 25 ton/ha of vermin composting sewage sludge. (a) Number of leaves per plant (NLP); (b) Plant height (PH); (c) Root diameter (RD); and (d) Tubercle production (TP).

\subsection{Statistical Evaluation}

In order to compare the effects of the corresponding treatment levels of 25 ton/ha of sewage sludge-SS and sewage sludge vermin compost-SSV on the radish, the Student " $\mathrm{t}$ " test was performed in order to examine the hypothesis $\mathrm{H}_{0}$ and $\mathrm{H}_{1}$ (Table 3 ). This test compares the mean values of both treatments, using the value of the significance level (observing the value of p) which makes the hypothesis valid. Note that in every case the value of $p$ is superior to the level of significance $(0.05)$ of all dependent variables. This result means that the treatments compared produce the same effects. Hence the need to take the economic analysis into account before choosing which "in natura" or vermin compost fertilizer to use.

The results of pH, EC, P and OM of the soil treated with equivalent levels of $0,25,50$ and 75 ton/ha of sewage sludge-SS are presented using box plot graphics. These graphics are used so as to be able to visualize values from the perspective of both the possibility of the equality of the mean values as well as of the dispersion values of each set of samples (using the same treatment). In these graphics, the tendencies of dependent variables can be observed when the factor or independent variable varies.

In Figure 2(a), note that, by the end of the experiment, the $\mathrm{pH}$ of the soil $\mathrm{pH}$ presented from 6.0 (with a level of zero ton/ha) to 6.5 (with a level of 50 ton/ha). Such findings demonstrate the ability of sewage sludge without prior whitewashing to increase the $\mathrm{pH}$ of soils [39]-[41]. In the cases, the authors attribute the neutralizing effect to the reaction involved in degrading the organic compounds of the waste. The levels of 25 and 75 ton/ha of sewage sludge presented similar statistical results, at a 5\% level of significance by the statistical tests [42].

The electric conductivity (EC) of the soil (Figure 2(b)) was significantly influenced by the interactions between sewage sludge treatments. Considering the behavior of EC amongst the levels of SS, it was verified that 
Table 3. Response of the student "t” test to compare the corresponding significance level of 25 ton/ha of sewage sludge- SS and the equivalent of 25 ton/ha of sewage sludge vermin compost-VSS.

\begin{tabular}{cccccc}
\hline Depent variable * & SSV & SS & T & g l & P \\
\hline NLP & 7.40000 & 7.80000 & -2.82843 & 2 & 0.105573 \\
PH & 17.80000 & 18.00000 & --- & 2 & -- \\
RD & 4.28500 & 3.97500 & 1.11391 & 2 & 0.381236 \\
TP & 17.80500 & 17.78000 & 0.06043 & 2 & 0.957305 \\
\hline
\end{tabular}

*NLP = number of leaves per plant; $\mathrm{PH}=$ plant height-cm; RD = root diameter $-\mathrm{cm}$; $\mathrm{TP}=$ tubercle production- - ton/ha.

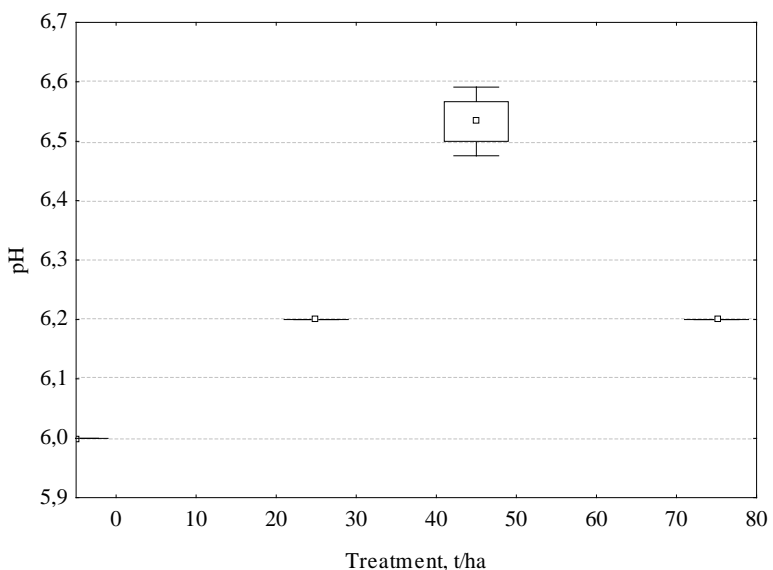

(a)

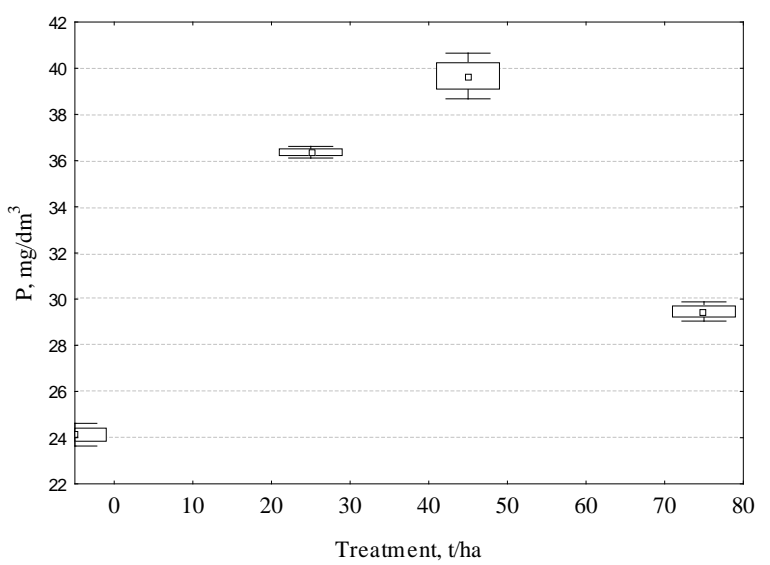

(c)

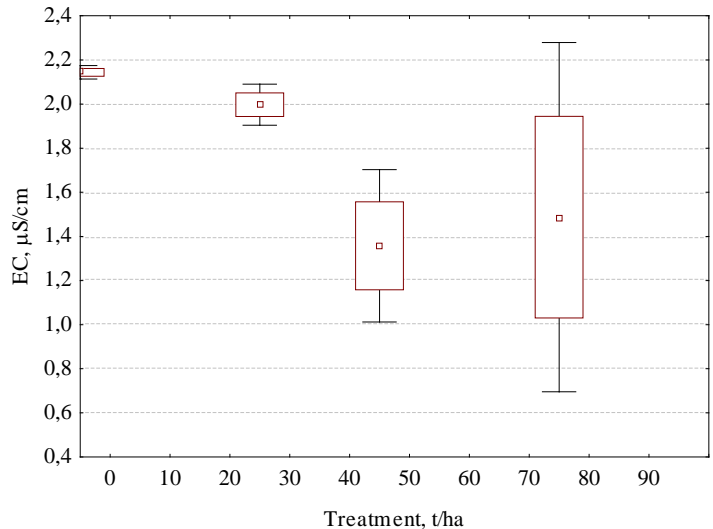

(b)

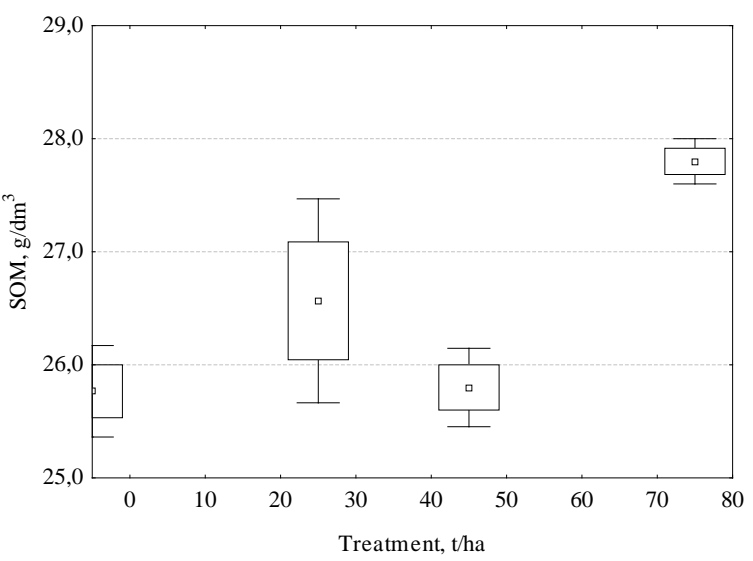

(d)

Figure 2. Hydrogen ionic potential—pH (a) electric conductivity-EC; (b) available phosphorus—P; ( c) and organic matter of the soil treated with sewage sludge-SOM; (d) of the soil treated with sewage sludge.

as the levels increase, there is a trend for the values of EC to decrease. This decrease in the saline concentration of the surface of the soil is probably due to soluble or in suspension ions being washed out, caused by the run-off flow of water due to rainfall and/or irrigation. Similar patterns were obtained by Epstein et al. [39] and Harding et al. [43], who attributed the EC values of soils treated with sewage sludge to the concentrations of the $\mathrm{Ca}^{2+}, \mathrm{Mg}^{2+}$ and $\mathrm{Cl}$-ions present in the residue incorporation layer. In accordance with this finding, Chibuike and Obiora [44] found significant correlations between the electric conductivity of soils excessively treated with high rates of residue and their concentrations of these ions.

The EC of the soil at all levels of SS and during the entire experiment remained below $2000 \mu \mathrm{S} / \mathrm{cm}$, the threshold above which soils are considered saline [45]. It must be pointed out, however, that adopting this parameter 
Table 4. Results of the $t$ test for the comparison between the corresponding level of 25 ton/ha of sewage sludge-SS and the equivalent level to 25 ton/ha of sewage sludge vermin compost-SSV.

\begin{tabular}{cccccc}
\hline Dependent variables* & LEV & LE & T & g l & P \\
\hline P & 39.52000 & 36.38000 & 11.9711 & 8 & 0.000002 \\
pH & $6.30000 \mathrm{a}$ & $6.20000 \mathrm{a}$ & --- & 8 & 0.031932 \\
$\mathrm{CE}$ & 2.08200 & 1.98600 & 2.5936 & 8 & 0.114088 \\
$\mathrm{MO}$ & $26.0800 \mathrm{~b}$ & $26.78000 \mathrm{~b}$ & -1.7734 & 8 & 8 \\
\hline
\end{tabular}

$\mathrm{P}=$ interchangeable phosphorus; $\mathrm{pH}\left(\mathrm{H}_{2} \mathrm{O}\right)$ = hydrogen ionic potential. Ratio 1:2.5 (soil: water); $\mathrm{CE}=$ electric conductivity- $\mu \mathrm{S} / \mathrm{cm}$; $\mathrm{MO}=$ organic matter.

does not provide a solid indication as to the degree of salinization of the soil of the experiment, bearing in mind that this criterion was developed based on the conductivity of saturation extracts. In addition, there is the possibility of depending on the kind of soil and the local rainfall pattern for the levels of the residues used in this experiment as having occasioned, even transiently, salinity problems and their adverse effects on the development of the plant.

The available $\mathrm{P}$ values in the plots fertilized with sewage sludge increased to a level of 50 ton/ha in comparison with the non-fertilized fields (Figure 2(c)). This was probably due to the medium to high rate (45 mg/kg) of this element in the sewage sludge used (Table 1). This effect could also be related to the presence of available forms of phosphorus in SS [46].

The organic matter content (Figure 2(d)) found in the soil does not indicate there was a considerable increase due to the levels of sewage sludge used, supposedly because of the presence of organic compounds such as lignin, cellulose, lipids, humus substances, greases, waxes, oils and resins [47], which based on the data could not result in the soil-plant system being benefitted [48].

\subsection{Comparison of the Organic Treatments}

In order to compare the effects in the soil of the treatment with the corresponding level of 25 ton/ha of sewage sludge_-SS and of sewage sludge vermin compost_-SSV, the Student " $\mathrm{t}$ " test was applied so as to verify the hypothesis $\mathrm{H}_{0}$ and $\mathrm{H}_{1}$ (Table 4). Note that in most cases the $\mathrm{p}$ value remains below the level of significance (0.05) for all the dependent variables. Such results imply that the treatments being compared have different effects. Only organic matter produces a similar effect because its significance value is above the level of significance of $5 \%$.

\section{Conclusion}

The characterization of sewage sludge is an important parameter for applying sewage sludge, as nutrient supplementation, in the soil for agricultural purposes. In addition, the cultivation of radish showed a positive response to the levels of 25 to 50 ton/ha of sewage sludge used. The use of corresponding levels of 25 ton/ha of sewage sludge was statistically similar to the same levels of sewage sludge vermin compost by California Red, with the exception of organic matter. The production of the "Crimson Giant” radish cultivar remained at the accepted interval for this vegetable. The use of sewage sludge levels of 25 to 50 ton/ha positively increases the pH to 6.5, decreases the electric conductivity (EC), and OM of the soil with a linear effect of the levels used. The nutrient contents (nitrogen and phosphorous) were high in all levels of the sludge samples taken from the anaerobically digested sewage sludge containing the highest concentrations. Generally higher C/N ratios were recorded in the sludge samples which are an indication that there is limited mobilization of nitrogen by incorporation into cell mass which makes the nitrogen contents available at a later period when plants most need them during their growth period. The results point to families increasing their consumption of radish as well as the perspective of trading conditions for the surplus products being improved. The results provided a better understanding of the use of sewage sludge as a promising fertilizer of the soil. They also show there can be an approximately $17 \%$ increase in mean family income from the sale of radish fertilized with sewage sludge; TP (ton/ha) values can increase by up to $43.47 \%$ using $25 \mathrm{SS}$, and the highest income per plot corresponded to US\$6.20 when the controlled treatments were compared. 


\section{Acknowledgements}

The research was supported by the International Federation of Catholic Universities (FIUC), the National Council for Scientific and Technological Development (CNPq), and the Science and Technology Foundation of the State of Pernambuco (FACEPE). The authors are also grateful to the Catholic University of Pernambuco for the use of laboratories.

\section{References}

[1] Andreoli, C.V., Lara. A.I. and Fernandes, F. (2001) Reciclagem de biossólidos: Transformando problema em solução. SANEPAR, 2nd Edition, Curitiba, Paraná, Brasil.

[2] Albuquerque, H.C., Zuba Junio, G.R., Sampaio, R.A., Fernandes, L.A., Zonta, E. and Barbosa, C.F. ( 2015) Yield and Nutrition of Sunflower Fertilized with Sewage Sludge. Revista Brasileira Engenharia Agrícultura Ambiental, 19, 553-559. http://dx.doi.org/10.1590/1807-1929/agriambi.v19n6p553-559

[3] Kabirinejad, S. and Hoodaji, M. (2012) The Effects of Biosolid Application on Soil Chemical Properties and Zea Mays Nutrition. International Journal Recycling Organic Waste Agriculture, 1, 4-5. http://dx.doi.org/10.1186/2251-7715-1-4

[4] Andrade, C.A., Oliveira, C. and Cerri, C.C.(2005) Organic Matter Quality and Carbon and Nitrogen Stocks in an Oxisol Treated with Biosolids and Cultivated with Eucalyptus. Revista Brasileira de Ciência do Solo, 29, 803-816. http://dx.doi.org/10.1590/S0100-06832005000500016

[5] Bittencourt, S., Serrat, B.M., Andreoli, C.V., Edilberto Nunes de Moura, E.N., Togny, F.L. and Silva, L.A.T.P. (2013) Sewage Sludge Subjected to Revolving: Effects on Total Solids, $\mathrm{pH}$ and Viable Helminth Eggs. Revista Acadêmica Ciências Agrárias Ambientais, 11, S191-S200. http://dx.doi.org/10.7213/academica.10.S01.AO22

[6] Von Sperling. M. (2002) Lodos Ativados. Editora UFMG, Belo Horizonte.

[7] Bruno, R.L.A., Viana, J.S., Silva, V.F., Genildo Bandeira Bruno, G.B. and Moura, M.F. (2007) Production and Quality of Seeds and Roots of Carrot Cultivated under Organic and Mineral Fertilization. Horticultura Brasileira, 25, 170-174. http://dx.doi.org/10.1590/S0102-05362007000200008

[8] Liu, T., Liu, B. and Zhang, W. (2014) Nutrients and Heavy Metals in Biochar Produced by Sewage Sludgepyrolysis: Its Application in Soil Amendment. Polish Journal of Environmental Studies, 23, 271-275.

[9] Cuba, R.S., Carmo, J.R., Souza, C.F. and Bastos, R.G. (2015) Potencial de efluente de esgotodoméstico tratado comofonte de água e nutrientes no cultivo hidropônico de alface. Ambiente \& Água-An Interdisciplinary Journal of Applied Science, 10, 575-586.

[10] Nikzad, E., Kalbasi, M., Hoodaji, M. and Fallahzade, J. (2015) Effect of Urban Treated Sewage Sludge on Concentration of Lead and Cadmium in Parsley and Its Soil. Research Journal Soil Biology, 6, 115-124.

[11] Ramamurthy, M., Umavathi, S., Thangam, Y. and Mathivanan, R. (2015) Effect of Vermicompost on Tuber Yield Status of Radish Plant Raphanus sativus L. International Journal of Advanced Research in Biological Sciences, 2, 50-55. http://www.ijarbs.com/pdfcopy/aug2015/ijarbs7.pdf

[12] Lopes, M.S. (1989) Salinidade: Quais as conseqüências. Lavoura Arrozeira, 42, 6-10. http://www.unicap.br/tede//tde_busca/arquivo.php?codArquivo=379

[13] Özyazıcı, M.A. (2013) Effects of Sewage Sludge on the Yield of Plants in the Rotation System of Wheat-White Head and Cabbage-Tomato. Eurasian Journal of Soil Science, 2, 35-44. http://www.fesss.org/download/arsiv/GC2O13KJ.pdf

[14] Ribeirinho, V.S., Melo, W.J., Silva, D.H., Figueiredo, L.A. and Melo, G.M.P. (2012) Fertilidade do solo. Estadonutricional e produtividade de girassol. Em função da aplicação de lodo de esgoto. Pesquisa Agropecuária Tropical, 42, 166-173. http://www.scielo.org/php/index.php

[15] Mtshali1, J.S., Tiruneh, A.T. and Fadiran, A.O. (2014) Characterization of Sewage Sludge Generated from Wastewater Treatment Plants in Swaziland in Relation to Agricultural Uses. Resources and Environment, 4, 190-199. http://www.wtwst.org.ua/Abstracts_PURE_WATER_2015.pdf

[16] Moreira, R.S., Mincato, R.L. and Santos, B.R. (2013) Heavy Metals Availability and Soil Fertility after Land Application of Sewage Sludge on Dystroferric Red Latosol. Ciência e Agrotecnologia, 37, 512-520. http://dx.doi.org/10.1590/S1413-70542013000600004

[17] Kauthale, V.K., Takawale, P.S., Kulkarni, P.K. and Daniel, L.N. (2005) Influence of Flyash and Sewage Sludge Application on Growth and Yield of Annual Crops. International Journal of Tropical Agriculture, 23, 49-54. http://baif.org.in/

[18] Latare, A.M., Kumar, O., Singh, S.K. and Gupta, A. (2014) Direct and Residual Effect of Sewage Sludge on Yield, Heavy Metals Content and Soil Fertility under Rice-Wheat System. Ecological Engineering, 69, 17-24. 
http://isa.niscair.res.in/isatest.jsp?ttype3=16\&ttype2=Feb http://dx.doi.org/10.1016/j.ecoleng.2014.03.066

[19] Ramamurthy, M., Umavathi, S., Thangam, Y. and Mathivanan, R. (2015) Effect of Vermicompost on Tuber Yield Status of Radish Plant Raphanus sativus L. International Journal of Advanced Research Biological Sciences, 2, 50-55. http://www.ijarbs.com/pdfcopy/aug2015/ijarbs7.pdf

[20] Camargo, L.S. (1981) As hortaliças e seu cultivo. Fundação Cargill, Campinas, 321 p.

[21] Filgueira, F.A.R. (2007) Novo manual de olericultura: Agrotecnologia moderna na produção e comercialização de hortaliças. 3rd Edition, UFV, Viçosa, 421 p.

[22] Suresh, K.D., Sneh, G., Krishn, K.K. and Mool, C.M. (2004) Microbial Biomass Carbon and Microbial Activities of Soils Receiving Chemical Fertilizers and Organic Amendments. Archives of Agronomy and Soil Science, 50, 641-647. http://dx.doi.org/10.1080/08927010400011294

[23] Coutinho, E.L.M., Natale, W. and Souza, E.C.A. (1993) Adubos e corretivos: Aspectos particulares na olericultura. In: Ferreira, M.E., Castellane, P.D. and Cruz, M.C.P., Eds., Nutrição e adubação de hortaliças, Potafós, Piracicaba, 85-140.

[24] Silva Jr., A.A., Macedo, S.G. and Stuker, H. (1995) Utilização de esterco de peru na produção de mudas de tomateiro. (Boletim Técnico. 73), EPAGRI, Florianópolis, 28 p. http://www.scielo.org/php/index.php

[25] Dutra, M., Deboni, T.C., Volpi, P.S.B., Matias, J.F.G. and Nesi, B.Z. (2014) Avaliação produtiva de rabanete Raphanus sativus L. submetido a preparados homeopáticos de tiririca Cyperus rotundus L. Revista Brasileira de Agroecologia, 9, 151-159.

[26] Trani, P.E., Feltrin, D.M., Pott, C.A. and Schwingel, M. (2007) Evaluation of Substrates in the Production of Lettuce Plantlets. Horticultura Brasileira, 25, 256-260. http://dx.doi.org/10.1590/S0102-05362007000200025

[27] Marcos Filho, J. and Kikut, A.L.P. (2005) Vigor de sementes de rabanete e desempenho de plantasem campo. Revista Brasileira de Sementes, 28, 44-51. http://www.scielo.br/pdf/rbs/v28n3/07.pdf http://dx.doi.org/10.1590/S0101-31222006000300007

[28] Embrapa (1999) Centro Nacional de Pesquisa de Solos (Rio de Janeiro. R.J). Sistema Brasileiro de Classificação de Solos. Embrapa, Brasília, 412 p.

[29] Camargo, M.N., Klamt, E. and Kauffman, J.H. (1987) Classificação de solos usada em levantamentos pedológicos no Brasil. Sociedade Brasileira de Ciência do Solo, 12, 11-33.

[30] Koffler, N.F., Lima, J.F.W.F., Lacerda, M.F., Santana, J.F. and Silva, M.A. (1986) Caracterização edafo-climática das regiões canavieiras do Brasil: Pernambuco. MIC/PLANALSUCAR, Piracicaba, 85 p.

[31] Ministério da Agricultura do Brasil (1973) Departamento Nacional de Pesquisa Agropecuária. Divisão de Pesquisas Pedológicas. Levantamento exploratório-reconhecimento dos solos do Estado de Pernambuco. Recife, 431 p.

[32] Ministério da Agriculturado Brasil (1979) Superintendência do Planejamento. Aptidão agrícola das terras de Pernambuco. BINAGRI (Coleção Estudos Básicos para Planejamento Agrícola), Brasília, 98 p.

[33] Embrapa (1997) Serviço Nacional de Levantamento e Conservação de Solo (Rio de Janeiro. R. J). Manual de métodos de análise de solo. Rio de Janeiro, 400 p.

[34] American Public Health Association (APHA) (1999) Standard methods for the examination of water and wastewater. 20th Edition, APHA, Washington DC, 1268 p.

[35] Yagioka, A., Komatsuzaki, M. and Kaneko, N. (2014) The effect of minimum tillage with weed cover mulching on organic daikon (Raphanus sativus var. longipinnatus cv. Taibyousoufutori) yield and quality and on soil carbon and nitrogen dynamics. Biological Agriculture \& Horticulture: An International Journal for Sustainable Production Systems, 30, 228-242. http://dx.doi.org/10.1080/01448765.2014.922897

[36] Statistica 6.0. Statistic for Windows. Statsoft. USA. 2001. https://software.dell.com/register/72480

[37] Nunes, M.A., Dias, M.A., Gaspar, A.M., Oliveira, M.D., Pinto, E. and Carapau, A.L. (1981) Análise do crescimento da beterraba sacarina em cultura de primavera. Agricultura Lusitana, 40, 217-240. http://www.scielo.br/scielo.php?script=sci_nlinks\&ref=000089\&pid=S0102-0536200200030002200014\&lng=en

[38] Haag, H.P. and Minami, K. (1987) Nutrição mineral de hortaliças: LXIII. Requerimento de nutrientes pela cultura da beterraba. Anais da Escola Superior de Agricultura “Luiz de Queiroz”. Piracicaba, 44, 401-407.

[39] Epstein, E., Taylor, J.M. and Chaney, R.L. (1976) Effects of Sewage Sludge and Sludge Compost Applied to Soil on Some Soil Physical and Chemical Properties. Journal of Environmental Quality, 5, 422-426. http://dx.doi.org/10.2134/jeq1976.00472425000500040021x

[40] Stark, S.A. and Clapp, C.E. (1980) Residual Nitrogen Availability from Soils Treated with Sewage Sludge in a Field Experiment. Journal of Environmental Quality, 9, 505-512. 
http://dx.doi.org/10.2134/jeq1980.00472425000900030036x

[41] Logan, T.J., Lindsay, B.J., Goins, L.E. and Ryan, J.A. (1997) Field Assessment of Sludge Metal Bioavailability to Crops Sludge Rate Response. Journal of Environmental Quality, 26, 534-550. http://dx.doi.org/10.2134/jeq1997.00472425002600020027x

[42] Montgomery, D.C. (2001) Design and Analysis of Experiments. John Wiley \& Sons, New York, 372 p.

[43] Harding, S.A., Clapp, C.E. and Larson, W.E. (1985) Nitrogen Availability and Uptake from Field Soils Five Years after Addition of Sewage Sludge. Journal of Environmental Quality, 14, 95-100. http://dx.doi.org/10.2134/jeq1985.00472425001400010019x

[44] Chibuike, G.U. and Obiora, S.C. (2014) Heavy Metal Polluted Soils: Effect on Plants and Bioremediation Methods. Applied and Environmental Soil Science, 2014, Article ID: 752708. http://dx.doi.org/10.1155/2014/752708

[45] Marchio, L., Assolari, S., Sacco, P. and Zerbi, G. (2004) Phytoextraction of Heavy Metals Bycanola (Brassica napus) and Radish (Raphanus sativus) Grown on Multicontaminated Soil. Environmental Pollution, 132, 21-27.

[46] Jiboye, B., Akinremi, O.O. and Racz, G.J. (2004) Laboratory Characterization of Phosphorus in Fresh and Oven-Dried Organic Amendments. Journal of Environmental Quality, 33, 1062-1069. http://dx.doi.org/10.2134/jeq2004.1062

[47] Clapp, C.E., Stark, S.A., Clay, D.E. and Larson, W.E. (1986) Sewage Sludge Organic Matter and Soil Properties. Developments Plant Soil Sciences, 25, 209-253. http://dx.doi.org/10.1007/978-94-009-4426-8_10 http://link.springer.com/chapter/10.1007\%2F978-94-009-4426-8 10\#page-1

[48] Hohla, G.N., Jones, R.L. and Hinesly, T.D. (1978) The Effect of Anaerobically Digested Sewage Sludge on Organic Fractions of Blount Silt Loam. Journal of Environmental Quality, 7, 559-563. http://www.scielo.br http://dx.doi.org/10.2134/jeq1978.00472425000700040018x 